\title{
Forest Regulatory Frameworks and Outcomes: An Assessment of Flegt and Timber Exploitation Activities in Ghana
}

\author{
Gordon Kofi Sarfo-Adu \\ Forestry Commission \\ Corporate Planning Manager
}

\begin{abstract}
The EU Forest Law Enforcement, Governance and Trade (FLEGT) Action Plan in 2003 was aimed at addressing illegal logging and to check the trade of illegal timber products in global markets to ultimately control deforestation and forest loss. Ghana was among the first timber exporting countries to ratify the VPA in the year 2007. This study set out to examine how the ratification and enforcement of the VPA protocols has influenced forest governance and timber harvesting activities in Ghana. In other words, to what extent has the enforcement of FLEGT VPA protocols in Ghana contributed to forest governance and illegal timber trading activities in Ghana? The qualitative case study design was employed to gather data from purposively selected respondents. The study established that VPA implementation has reduced the incentives to engage in illegal logging because the control mechanisms put in place will easily detect illegality tendency of prosecution will be high and the tendency of not meeting international market standards are also high. It emerged the VPA helps check the rots in timber trade and exploitation through its multi-stage transparency and accountability systems which blows those covers with tendency to fuel illicit timber trading activities. The study proposes two clear measures which could help prevent, detect and deter people from such illegal timber trade.
\end{abstract}

Keywords: Forest governance, timber exploitation; timber trade; illegal logging; FLEGT

DOI: $10.7176 / \mathrm{JRDM} / 73-03$

Publication date: February $28^{\text {th }} 2021$

\subsection{Introduction}

Forest resources have many uses and different stakeholders attach specific utility to these resources; some stakeholders put a demand on the resources for their socio-economic livelihoods. The notion of forest governance entails all formal and informal structures as well as the processes, norms, principles for controlling and planning in the forest sector, their use and their preservation (Giessen \& Buttoud, 2014). It also includes the interactions between public and private actors as well as consequences of these interactions on forests (ibid). All these are geared towards effective governance of forest resources with a view to prevent forest degradation which among other things are caused by illegal logging.

The notion of illegality in forest governance refers to cutting of forest trees by adopting procedures and activities that are inconsistent with the national laws (Smith, 2002). Illegal loggers in many cases connive with government officials charged with forest protection. Consequently, illegality and corruption have emerged as a key challenge for forest protection and management (The Guardian, 2014; Smith et al, 2015). Illegality in forest cutting activities in most cases occur and affect forest governance in at least three main forms: Initially, the contractor may cut beyond the prearranged quantity of timber; the contractor may target the highly economic value trees species thereby leaving behind less valued trees species. Finally, the contractor mostly may tend to violate the instruction of sustainable tree logging and may resort to logging practices which are not sustainable (Amachar et al, 2012). Illegality in forest governance which takes any of the three forms above mostly have negative ramifications on sustainability of species which also has socio-economic and environmental consequences. The literature avers that the livelihoods of forest fringe communities are mostly negatively affected and destroyed in numerous ways (Solomon \& et al, 2015) whilst it inadvertently has high cost due revenue losses to the state (Forest Governance Integrity Program, 2011; World Bank, 2002).

The European Union (EU) observing these issues and its key role in the global timber market which have had some of the timber products come from countries where illegal timber harvesting practices prevail (Hoare, 2015), the EU has established a regulation to ensure this is stopped. It therefore, came up with the Forest Law Enforcement, Governance and Trade (FLEGT) Action Plan in 2003 which was aimed at addressing illegal logging and to check the trade of illegal timber products in global markets to ultimately control deforestation and forest loss (Brack, 2013). A main element of the FLEGT Action Plan has been the Voluntary Partnership Agreements (VPAs) between the European Union and timber producing countries. Ghana has been among the first countries to ratify this bilateral Voluntary Partnership Agreement in 2007 and went ahead to put in place the necessary institutional structures and frameworks to ensure all illegal logging and trading of timber are adequately checked and controlled.

Matching the stated expectations against enforcement of the VPA in Ghana, this study set out to examine how this has influenced forest governance and timber harvesting activities in Ghana. In other words, to what extent has the enforcement of FLEGT VPA protocols in Ghana contributed to forest governance and illegal timber trading 
activities in Ghana?

\subsection{Theoretical Framework}

\section{Theoretical framework: policy arrangement approach}

In this research, the policy arrangement approach (PAA) was used to frame the study. The concept of policy arrangement suggests temporary stabilization of the content and organization of a particular policy domain (Van Tatenhove et al, 2000) involving structures formed through processes and interactions among policy actors and rules (Arts \& Leroy, 2006). This approach is more appropriate when a research hinges on the dimensions of actors, power, rules and discourse (Arts \& Van Tatenhove, 2004; Arts \& Leroy, 2006). The framework pays peculiar attention to (1) institutional contexts in which policy actors must operate, (2) the substance of policy-making and (3) the power relations between the policy actors involved (Wiering \& Arts, 2006). As this proposed study discusses impact of VPA implementation on governance and institutional structures of Ghana as well as impact on forest practices, the PAA framework is more appropriate to frame the study. this framework has been applied to analyze dynamics of forest policies elsewhere, including the Netherlands (Veenman et al, 2002), Belgium (Van Gossum et al, 2011) and South Korea (Park \& Youn, 2013).

The PAA as theoretical framework rests on two key philosophies; (i) political modernization and (ii) policy arrangements. Political modernization entails the ever-changing interactions between the state, the market and civil society in political domains of society within national borders and beyond which is manifested in through globalization and Europeanization (Arts \& Van Tatenhove, 2006). An implication is that forest decision processes do not rest with governments of one state or the traditional forest sector alone but polycentric in nature (Verbij, 2008).

The policy arrangement is discussed along following four dimensions: (a) actors and their coalitions involved in the policy domain; (2) the division of resources between these actors (b) the rules of the game and (d) discourses (Arts \& Goverde, 2006; Arts et al., 2006).

\subsection{Conceptual Framework}

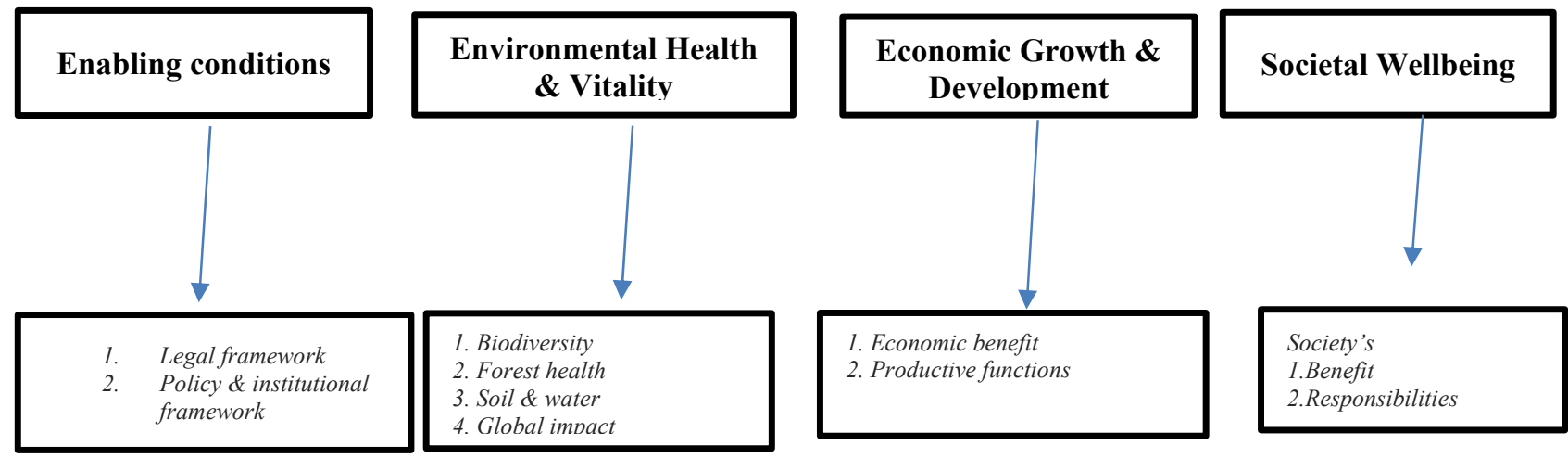

Figure 2.1: Conceptual framework

Source: Author's construct

Figure 2.1 illustrates the ideal conceptualization of how governance arrangements foster sustainable forest management and SFM outcomes. The figure shows four main elements with each of them possessing some peculiar set of factors or attributes.

\section{Enabling conditions}

A first element is 'enabling conditions' which indicates the overall governance arrangements that help in structuring the relationship between actors, their behavior patterns, the enabling and restraining factors among others. The enabling condition broadly encapsulates the legal framework, policy and institutional framework including the actors, roles and responsibilities, the benefit arrangements among others. The role of institutions is very crucial in this sustainable forest management drive. Institutions are defined to mean "man-made regulative structures for moderating human behaviors and relationships and coordinating decisions toward a desired goal; in other words, institutions are formally sanctioned rules of a society, which provide expectations, stability, and meaning to human relationships (Vatn, 2005; North, 2007).

Institutions are rules and regulations that structure how people relate with forest and its resources or how the actors relate to each other for the purposes of sustainable forest management. According to Wiering and Arts (2006), sustainable forest management regulations indicate the extent to which changes in forest management discourse are reflected in changes in general regulation, or the manifestation of policy content into formal rules. The institutional process remains the cornerstone for social interaction which assigns roles, enhances actions and 
also constrains behaviors; they are also critical to the decision making process and determinant of the extent to which decision making should be open or close, who should be involved as well as determines how conflicts are managed in society (North, 1991). Institutions have deliberately been designed with societal and organizational embedded values, interests, goals, and resources that constrain or enable human behaviour in society (North, 1991; Hodgson, 2006; Leftwich \& Hogg, 2007).

\section{Environmental Health \& Vitality}

The idea of governance and institutionalism (enabling conditions) is to help fashion out a profound environmental outcome. This is demonstrated in the second element 'environmental health and vitality'. The forest condition is expected to blossom with high influx and growth rate of biodiversity, the forest health is expected to be in good condition devoid of any unscrupulous degradation or tree felling, high retention of soil water and soil air, and should cumulatively lead to a global impact on overall forests growth. A major concern of SFM is to increase global impact of forests which has implication on carbon sequestration and climate change issues. Therefore, SFM is expected to put in place measures and mechanisms to promote tree species growth, their protection, regulated logging in a more sustainable way without compromising their regenerative capacities and more in a regulated cycle. By safeguarding long-term timber stocks, land rents for sustainably-managed natural forests remain competitive with rents for alternative land uses in the future, thus preventing eventual conversion to agriculture, pasture, and plantation forests (Blaser et al. 2011; Phelps et al., 2013).

This model is gradually finding its way in the tropics since it has proven to be an appropriate tool. For instance, Agrawal, (2005) reports that since the early 19th Century, FMPs have been attempted with varying implementation experiences for tropical forests (also Nasi \& Frost, 2009). Consequently, the area of tropical forests managed through FMPs increased by 30\% from 2005 to 2010, and now total 183 million hectares worldwide, or $46 \%$ of tropical production forests (Blaser et al., 2011).

\section{Economic Growth \& Development}

Forest products do have economic values and remain a major source of income to many tropical economies. Therefore, the idea of sustainable forest management does not seek to deprive countries and governments from gaining revenues from this enterprise but to fulfill this goal without compromising other relevant issues also. In this regard, it is prudent for governments to maximize economic returns they make out of their forest products to propel socio-economic development. In other words, SFM is also concerned with economic benefits from tree and forest resources as well as the productive functions of forests. It is against this backdrop that countries that reserve their forests for carbon sequestration purposes get paid for carbon credits which is to signal that the quest for SFM and economic growth or productive functions of forests are not mutually exclusive.

\section{Societal Wellbeing}

A major goal of sustainable forest management is to ensure forest fringe community members, groups and their leaders also get better off for their role played in the governance process. It should be noted that these community members and groups in most cases had derived and continue to derive their source of livelihoods from the forest and its products therefore an attempt to strengthen SFM should also have them in the equation. Any attempt at promoting forest vitality or health which neglects the wellbeing of community members will not be sustainable but would experience a debacle. Barrow et al, (2016) contend that rural communities need rights to, and responsibilities for the sustainable management of forests, be able to decide on the value of such resources, identify enterprises, seek financial and technical support for developing such enterprises, and establish and nurture sustainable institutions that assure more equitable benefit accrual. In order to foster sustainable forest management practices, the role of communities, their participation and empowerment has been described as very essential to SFM drive. For example, new forestry policies and laws formulated in Cameroon, DR Congo, Gabon, Equatorial Guinea, the Central Africa Republic and the Republic of Congo Brazzaville (CBFP 2006) take into account the rights of local communities in forest management and access to associated benefits (Karsenty 1999, 2004; Oyono 2007). They are oriented towards decentralization (CBFP 2006; Oyono, 2007), but many such policies are yet to be implemented (White \& Martin 2002; Oyono 2007). Recognizing communities and indigenous people's rights is essential for advancing human rights, alleviating poverty and conserving the forest.

\subsection{Methodology}

The case study design within the qualitative research approach of social research was adopted for the study. The purposive sampling technique was used to select relevant informants to participate in the study. With qualitative study, researchers do not place much emphasis on numbers but the quality of information that would be elicited from participants (Sandelowski, 1995). Both primary and secondary sources of data were used to undertake the study. Primary data was elicited from respondents along the value chain of enforcing Ghana's VPA.

The purposive sampling technique was used to select fifty-nine (59) key actors from the Forestry Commission 
which is the lead government institution for VPA implementation in Ghana and expected to contribute about eighty per cent of VPA implementation. A newly created TVD at FC coordinates VPA implementation process. Key administrative and implementing officials of the relevant units/departments at the Forestry Commission; relevant committees/councils and working groups for VPA implementation and a VPA Secretariat as well as participants from the Ministry of lands and natural resources. Key actors from the Resource Management Support Centre (RMSC), the Forest Service Division (FSD) and the Timber Industry Development Division (TIDD) of Ghana's Forestry Commission were selected. Tropenbos International, a non-state organization which has been active in VPA processes was selected.

Secondary data involved data from journal sources, scholarly books, internet sources, published and unpublished materials relevant to the study. Again, documents from Ministry of lands and natural resources, Forestry Commission of Ghana; Ghana-EU team bulletins and other releases were resorted to.

The main instrument for primary data collection was through the use of in-depth interviews and semistructured questionnaires. In-depth interview involves face-to-face interaction with key respondents. Data was recorded and transcribed which was subsequently organized through thematic analysis.

\subsection{Data and Discussion}

The study set out to assess how implementation of the VPA has influenced forest trade and timber exploitation in Ghana. Data was gathered through in-depth interviews and semi-structured questionnaires. From interactions with key respondents, the following key themes have been derived and well discussed. This section is aimed at examining the implication of the Voluntary Partnership Agreement on timber exploitation and trade in Ghana. All respondents answered in the affirmative that VPA implementation has had a favorable impact on forest resources exploitation and trade. They remained positive on the relevance of VPA in promoting good governance in the forestry sector due to transparency it has introduced. Additionally, the process has been effective in combating illegal logging which also helps in safeguarding the environment. The VPA process has also come with increasing revenue derived from forest resources and benefits to communities, land owners and relevant stakeholders. These are discussed in the following themes.

\subsubsection{Reduction in illegal logging}

The data revealed that the introduction of the VPA and its intrinsic elements have practically contributed to a reduction in illegal logging.

Table 4.1: VPA/FLEGT is helping to control illegal logging

\begin{tabular}{|ll|l|l|l|l|}
\hline & Frequency & Percent & Valid Percent & Cumulative Percent \\
\hline \multirow{4}{*}{ Valid } & Strongly agree & 9 & 27.3 & 27.3 & 27.3 \\
& agree to an extent & 10 & 30.3 & 30.3 & 57.6 \\
& not sure & 6 & 18.2 & 18.2 & 75.8 \\
& strongly disagree & 1 & 3.0 & 3.0 & 78.8 \\
& no answer & 7 & 21.2 & 21.2 & 100.0 \\
& Total & 33 & 100.0 & 100.0 & \\
\hline
\end{tabular}

Source: Fieldwork, 2018

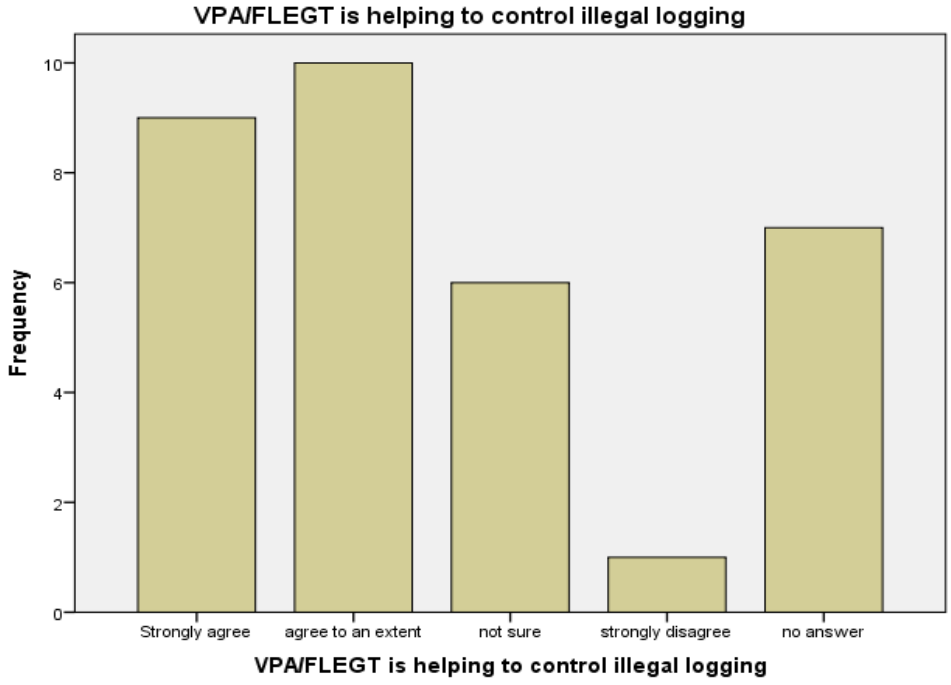

Figure 4.1 VPA and control of illegal logging

Source: Author's fieldwork, 2018 
From the table 4.1 and figure 4.2, 19 respondents representing 57.6 contend that the implementation of VPA has reduced illegal timber logging activities whilst 14 respondents representing 42.4 appear not very convinced. Those who were positive explained that the VPA has come with elements that make for transparency, accountability and traceability in the timber industry. The introduction of the WTS serves as disincentive to stakeholders in both local and international trade of wood to be circumspect in their activities. A key officer at the forestry services division noted:

"Illegal logging has gone down, however, this will be realized when the FLEGT licence is issued. From the deforestation analysis done using the hectares indicator method, deforestation resulting from illegal logging has reduced since 2016 (please can you get this data)

This was given support by another key officer at the TVD who explained:

"Yes, it has helped improve the governance structure of forest resources management... has curbed illegal logging as many structures or levels put in place make it impossible for most illegal logging to operate"

Bringing the argument closer home, an officer in charge of operations at the FSD revealed how the VPA tends to control illegal timber trade

"Laws on illegal timber are better enforced and illegally harvested timber can be traced from the market to the forest at stump site as well as the personnel who carried out the operations.... Illegal logging is reduced because one cannot export such products easily (Director of Operations, FSD)

However, those who were skeptical of the VPA success explained that the process should well ensure that timber in the domestic market as well as for other international markets conform to the legality principles.

\subsection{Multi-tier transparency}

The VPA process has introduced different accountability and transparency mechanisms along the timber trade value chain especially the introduction of independent monitor and technology for tracking wood source. In a survey with respondents, they expressed positive opinions on VPA and accountability.

Table 4.2: VPA and transparency in forest governance VPA/FLEGT is helping to improve transparency and accountability in forest business

\begin{tabular}{|c|c|c|c|c|c|}
\hline & & Frequency & Percent & Valid Percent & $\begin{array}{c}\text { Cumulative } \\
\text { Percent }\end{array}$ \\
\hline \multirow{5}{*}{ Valid } & Strongly agree & 16 & 48.5 & 48.5 & 48.5 \\
\hline & agree to an extent & 13 & 39.4 & 39.4 & 87.9 \\
\hline & not sure & 3 & 9.1 & 9.1 & 97.0 \\
\hline & no answer & 1 & 3.0 & 3.0 & 100.0 \\
\hline & Total & 33 & 100.0 & 100.0 & \\
\hline
\end{tabular}

Source: Fieldwork, 2018

VPAIFLEGT is helping to improve transparency and accountability in forest

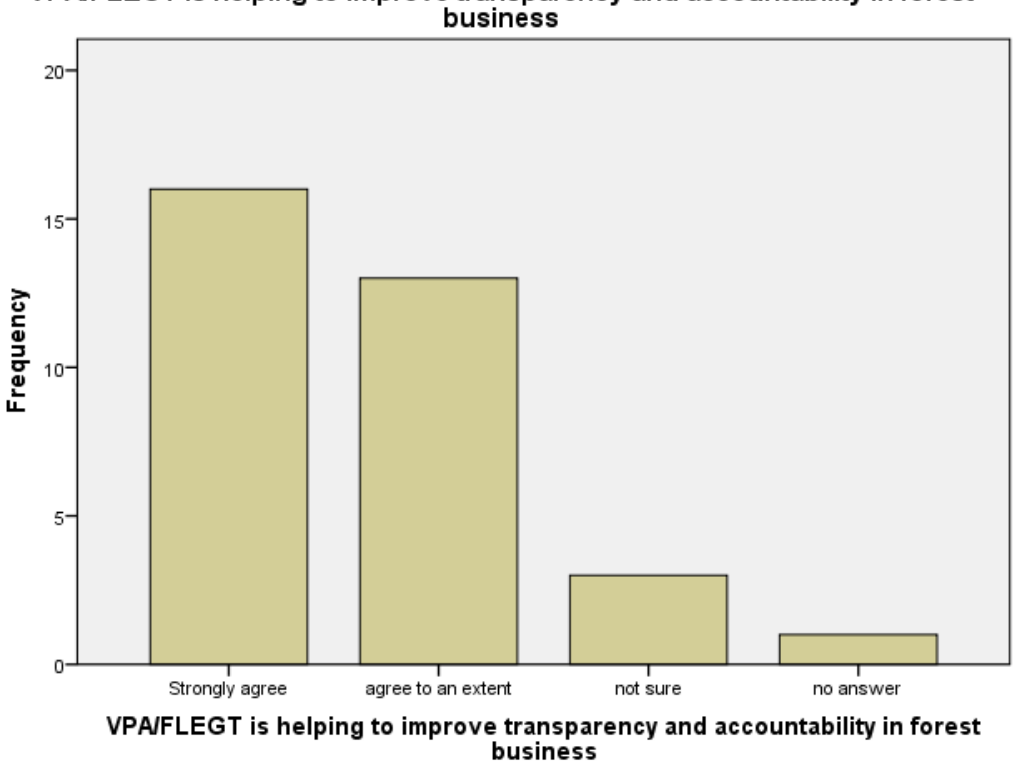

Figure 4.3: VPA and transparency in forest governance

Source: Fieldwork, 2018 
The enforcement of VPA has reduced a tendency to engage in illegal timber operations and trade. An officer at the TIDD noted:

"The multi-stakeholder approach in SRA signage and the presence of Independent Monitor and other relevant civil society organizations as observed, all geared towards improving the governance system.

For example, upon observing an appearance of anomaly regarding related data uploaded on to the WT system by the technical staff of the Juaboso, Sefwi Wiawso, Dormaa and Mankranso Forest Districts between the periods

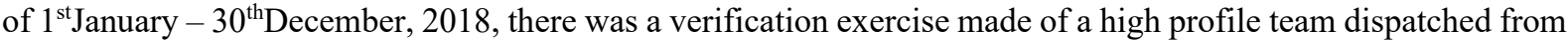
headquarters to the various forest districts to ascertain the nature of the problem. This was against a backdrop that the data in the system for the Districts between the above mentioned period had its elements mostly red flagged which has led to the difficulty of the data being approved by the respective District Managers as well as billing of the TIFs which is done by the accountant

\subsection{Prompt payment of timber royalties}

The timber trade is expected to benefit the state in terms of revenue, the private timber firms in terms of profits and more importantly the community members through royalties. The latter had been problematic over the years as there had been reports of delayed or unpaid royalties over time. In the survey, respondents indicated that the VPA implementation has improved collection of forest fees which helps the local communities. This illustrated in the table 4.3

Table 4.3: VPA/FLEGT and collection of forest fees

\begin{tabular}{|l|l|l|l|l|}
\hline & Frequency & Percent & Valid Percent & Cumulative Percent \\
\hline strongly agree & 15 & 45.5 & 45.5 & 45.5 \\
agree to an extent & 12 & 36.4 & 36.4 & 81.8 \\
not sure & 3 & 9.1 & 9.1 & 90.9 \\
Valid & 1 & 3.0 & 3.0 & 93.9 \\
disagree to an extent & 1 & 3.0 & 3.0 & 97.0 \\
strongly disagree & 1 & 3.0 & 3.0 & 100.0 \\
no answer & 33 & 100.0 & 100.0 & \\
Total & & &
\end{tabular}

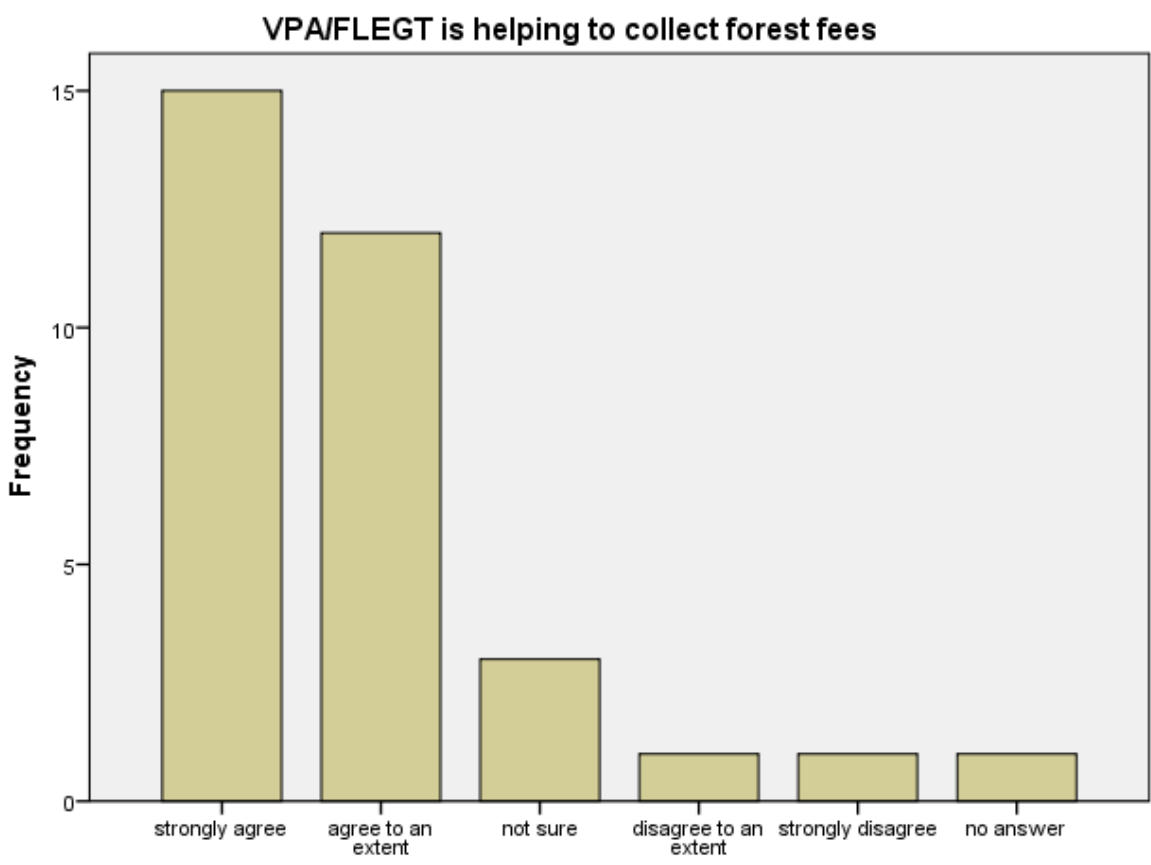

VPAIFLEGT is helping to collect forest fees

Figure 4.4: VPA and improvement in the collection of forest fees

From table 4.3 and figure 4.4, twenty-seven (27) out of thirty (33) respondents representing $81.8 \%$ agree that VPA implementation has helped in collecting forest fees which in the long run benefits the state through tax payments and to the communities through royalties or stumpage fees. With the introduction of VPA, payment for royalties is an entrenched part of the process which cannot be sidestepped. A manager at the GIS unit explained:

"the VPA process has ensured prompt payment of timber royalties resulting in high revenue generation to the government landowner and local communities through the prompt payment of SRAs The internal 
controls have been well built to ensure discipline among frontline forest managers

This was given support by an administrator at the TIDD who hit the nail on the head:

"Timber harvested cannot be exported if the timber royalties/stumpage is not fully paid... Fringe communities and resource owners... SRA signing and debt collection has become a condition for renewal of property mark"

Relating these findings to the conceptual framework underpinning the study (figure 4.1), the enabling conditions which are institutions and policy frameworks have helped in promoting forest governance. Institutions have been defined to mean "man-made regulative structures for moderating human behaviors and relationships and coordinating decisions toward a desired goal; in other words, institutions are formally sanctioned rules of a society, which provide expectations, stability, and meaning to human relationships (Vatn, 2005; North, 2007). In the narratives above, the rules are that without payment of royalties, timber cannot be deemed legal or cannot proceed along the value chain. The institutional process remains the cornerstone for social interaction which assigns roles, enhances actions and also constrains behaviors; they are also critical to the decision making process and determinant of the extent to which decision making should be open or close, who should be involved as well as determines how conflicts are managed in society (North, 1991). Institutions have deliberately been designed with societal and organizational embedded values, interests, goals, and resources that constrain or enable human behaviour in society (North, 1991; Hodgson, 2006; Leftwich \& Hogg, 2007).

From the above findings, it was unanimously reported that the VPA process has improved good governance in the forest sector, has greatly helped in combating illegal logging through its control mechanisms, which has implications on environmental health and vitality. Finally, the VPA implementation has led to an improvement in benefit sharing for communities and landowners which have implications on economic growth and development as well as societal well-being.

In a recent study, Hansen et al (2018) contend that VPA implementation has not improved tree tenure and benefit sharing practices, however, their study observes the VPA through its enforcement of Social Responsibility Agreements has significantly improved the benefits derived by local community members which to an extent addresses the question of social equity. The current study provides support to the latter that VPA through its strict enforcement of SRA and payment of all royalties to the relevant stakeholders before timber is declared legal helps local communities to derive benefits from timber. Hansen et al (2018) appear to be very critical of the VPA, but this current study contends that the reforms by VPA such as Timber Legality Assurance System, updated forest management plans, and an artisanal milling strategy, independent monitor, WTS to a greater extent help reduce tendencies for illegalities.

Atyi et al (2013) using content analysis without recourse to substantive empirical data appeared to be skeptical of Cameroun's signing of the VPA/FLEGT arrangement. The authors cite skeptical hypothesis including cost on forest managers and national governments. Despite the red flags raised by the scholars, the current study provides empirical evidence that the VPA/FLEGT with its intrinsic elements which cumulatively provide advantages offset any skepticism held. Therefore, despite the fact that its implementation is expensive especially with the WTS, the benefits derived cannot be overemphasized. In terms of timber exploitation, the tendency for timber companies and forest officials to engage in collusion is checked through this system as it has improved transparency and easy verification of timber source. The GWTS system will easily raise a red flag to draw attention of many other stakeholders or parties when any appearance of infringement or illicit practices is detected on the system. For instance, through these systems, the Ghana National Monitoring Taskforce impounded vehicles whose log measurement and conveyance certificates (LMCCs) differed from the book copies and this prompted an investigation which among other things was traced to two particular forest districts and two officials were banned from further issuing any license (GWTS Verification Report, 2019). In one of the Districts (G), the GWTS had detected at least some 94 LMCC red flags and 73 TIF red flags from January 2018 to April 2019. These red flags usually raise concern and paves way for further investigations which help to ascertain the nature of the infraction. These have helped to reduce the illegal trading of timber as well as reduction in the tendency of timber companies and forest officials to engage in collusion.

Deducing from a conventional input-output-analysis, Dieter (2009) carries out simulations to assess how international trade regime could foster illegal trade. The results suggest that international trade generally tends to increase the global domestic supply of illegally harvested timber by more than $70 \%$ in each scenario. This suggests that a VPA which seeks to deploy international trade to rather prevent illegal timber harvesting is a laudable policy. The current study provides empirical evidence to critique the model by Dieter (2000) that there are new international trade regimes which rather prevent illegal timber trade.

In a review of theoretical and empirical literature on forest governance, Sundström (2016) observes that bribery has become an a "door opener" for illegal activities to take place in forest management which also affects timber trade. The current study observes that the VPA and its intrinsic array of mechanisms serve as "door closer" to any intention of corruption and collusion in timber trade as the system can detect this act at any stage and could be traced to the source. 
Amacher et al (2012) examine how corruption influences government and forest officials' application of forest concession policy instruments such as royalty rates and payment, concession size, logging patterns and enforcement of logging standards and laws. They found out that loggers have the incentive to illegally harvest by taking much more volume than allowable limits, sidestepping sensitive tree harvesting requirements. They observe that corruption gets set in when forest inspectors get bribed by loggers to avoid being fined. The current study has observed that a tendency to bribe officials on the field is not a guarantee that loggers can get their consignment to a logical conclusion because the chain of controls is numerous and carried out by independent bodies along the value chain. Besides the introduction of WTS which is a computerized system to point to the very source, forest officials do not want to be accomplices because they can be traced. This suggests that the introduction of the VPA has reduced the intention to engage in illegal trade of timber.

\subsection{Conclusions and policy implications}

The paper has explored the implementation of the VPA and its implications on timber exploitation and trade. The study has explored the implementation of the VPA has had implications on timber exploitation and trade.

Using empirical data, the study has established that VPA implementation is helping to control illegal logging in the forestry sector of Ghana. Illegal logging had been on the increase because illegally acquired timber could easily penetrate the international market especially Europe which has been the biggest traditional destination point for timber. However, the introduction of VPA has reduced the incentives to engage in illegal logging because the control mechanisms put in place will easily detect illegality tendency of prosecution will be high and the tendency of not meeting international market standards are also high. These help drive a quest for sustainable mindset in the logging and exploitation of timber. The study concludes that VPA through its controls has reduced the incentives for forest officials and private companies to engage in collusion or illegal timber transactions.

The study observes that the VPA has introduced intense transparency and accountability measures in the timber trade industry. Due to the transparency and accountability, the rots in timber trade and exploitation have significantly reduced. The VPA has introduced multi-stage transparency and accountability systems which have blown the cover that fuels illicit timber trading activities. The VPA process among other objectives seeks to ensure legality assurance in the domestic timber trade also since a bulk of timber products are consumed or traded internally as illustrated in the figure below. The figure demonstrates that developing countries consume majority of the timber products in the domestic market and only export a few. Henceforth, the VPA implementation should use its transparency and compliance controls to help enhance transparency and accountability in the domestic trade of timber.

\begin{tabular}{|l|l|l|}
\hline Export & $\begin{array}{l}\text { Domestic consumption - } \\
\text { informal chainsaw milling }\end{array}$ & $\begin{array}{l}\text { Domestic consumption- } \\
\text { legal timber }\end{array}$ \\
\hline
\end{tabular}

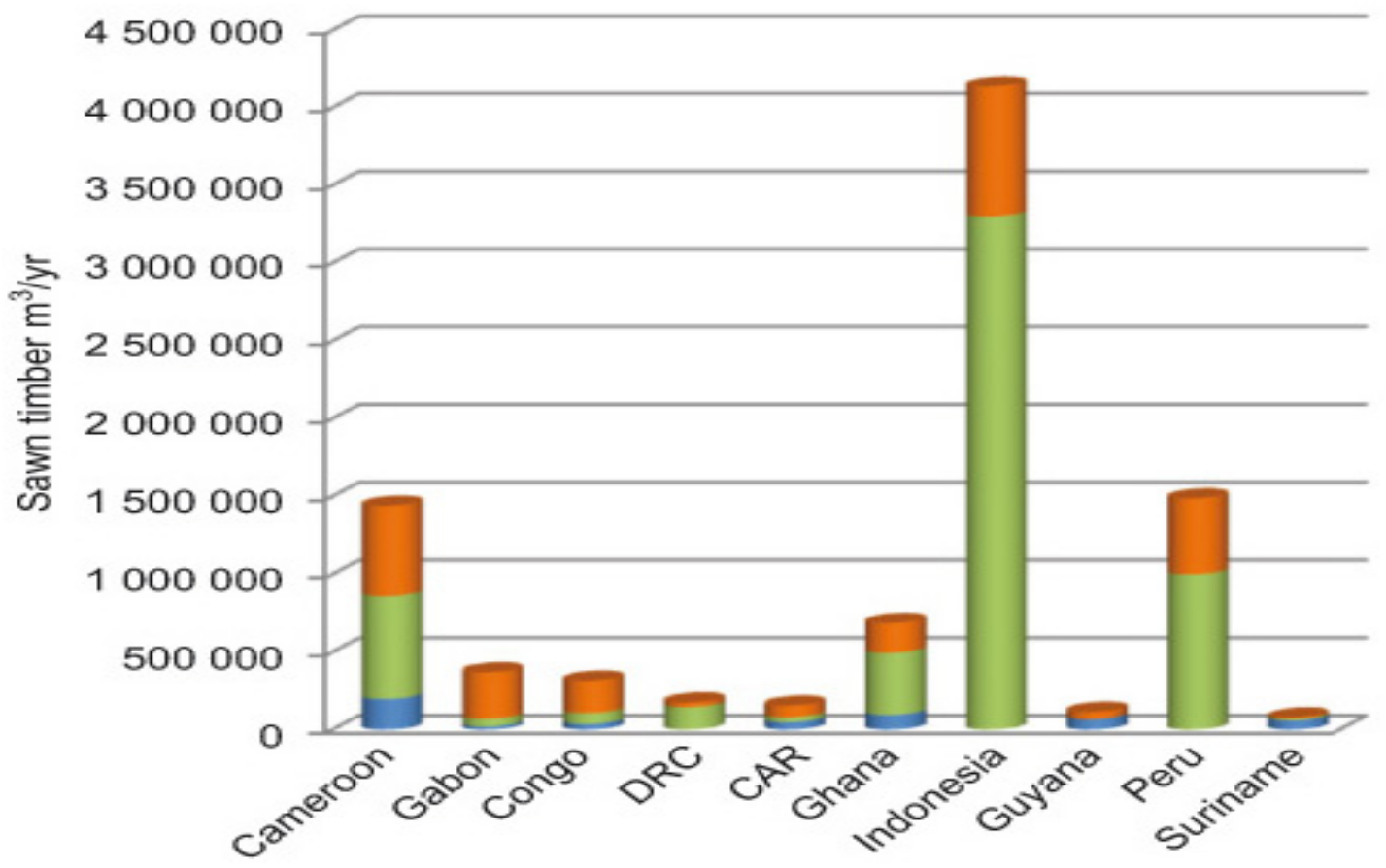

Figure 4.5: Domestic and international trade of timber products Source: Data from Wit et al (2010). 
Therefore, the deployment of the GWTS and multiple streams of verification as introduced by the VPA should be able to help officers clamp down on illegal logging, transportation and trading of illegal timber even within Ghana

Finally, the study concludes that VPA implementation comes with enhanced economic growth and development which comes through prompt payment of timber royalties and stumpage fees. This is a pre-condition to ascertain the legality and eligibility to meet the international market which is also the largest market for timber. Therefore, by paying attention to this criteria, VPA implementation ensures timber trade benefits the local communities.

The paper recommends for the strengthening of national capacities to enforce forest laws and regulations. The usual operational steps, from logging in clearly delineated large production forest, to timber processing in industrial plants and to export through a restricted number of customs checkpoints need to be relooked at. It is important to subject all timber leaving for exports to the VPA legality assurance tests. Forest certification should be prudently carried out and the accountability mechanisms should be widened. Even those timber which would be consumed internally requires effective monitoring and certification and the use of the GWTS should be applicable to so that such logs can be traced to source even when they are found on the market.

In other words, the commodity chain should be better controlled to guarantee the legality of the final product on both the international and domestic markets. The study proposes two measures which could be synergized. Firstly, a more rigorous control of the administrative practices to help prevent, detect and deter people from such illegal timber trade. So the stick approach which seeks to deter people should be infused with a carrot approach which seeks to provide incentives to encourage field agents to implement legality and report culprits.

Secondly, the study argues for the role of independent monitor to extend to the domestic timber logging and trading activities. By widening the accountability structures and mechanisms, the tendency for collusion will reduce.

It is prudent to reform the small-scale timber harvesting processes and the permitting processes. Some of the processes are cumbersome and very bureaucratic which tends to scare away the local loggers who are usually illiterates. For the chainsaw operator, poorly-adapted measures provide them incentives to engage in illegal loggings because such cumbersome process may either be beyond their reach or they may tend to engage in collusion with foresters. The study advances that procedures for securing legal permits need to simplified so that small-scale domestic chainsaw millers could come unto the legality umbrella.

\section{BIBLIOGRAPHY}

Arts, K., van der Wal, R., \& Adams, W. M. (2015). Digital technology and the conservation of nature. Ambio, 44(4), 661-673.

Atyi, R. E. A., Assembe-Mvondo, S., Lescuyer, G., \& Cerutti, P. (2013). Impacts of international timber procurement policies on Central Africa's forestry sector: The case of Cameroon. Forest policy and economics, $32,40-48$

Balsiger, J., \&VanDeveer, S. D. (2012). Navigating regional environmental governance. Global Environmental Politics, 12 (3), 1-17

Bammer, G. (2009). Enhancing research collaborations: Three key management challenges. Research Policy, 37 , $875-887$

Blaser, J. et al., (2011). Status of Tropical Forest Management 2011. ITTO Technical Series, 38, p.418.

Carabelli, E., Bigsby, H., Cullen, R., \& Peri, P. (2007). Measuring sustainable forest management in Tierra del Fuego, Argentina. Journal of Sustainable Forestry, 24(1), 85-108.

CARPE (2001). Central Africa and Forest Governance: Counter-balancing the Powers or Public and Private Interests. Central African Regional Program for the Environment

Cashore, B., \& Stone, M. W. (2012). Can legality verification rescue global forest governance?: Analyzing the potential of public and private policy intersection to ameliorate forest challenges in Southeast Asia. Forest policy and economics, 18, 13-22.

Chambers, R., \& Conway, G. (1992). Sustainable rural livelihoods: practical concepts for the 21 st century. Institute of Development Studies (UK).

Park, M. \&Youn, Y. (2013) Development of urban forest policy-making toward governance in the Republic of Korea. Urban For. Urban Green, 12, 273-281

Rametsteiner, E., Simula, M., (2003). Forest certification - an instrument to promote sustainable forest management? Journal of Environmental Management, 67(1), 87-98

Rhodes, R. A. W. (1996). The new governance: governing without government. Political studies, 44(4), $652-667$.

Ribot, J. (2004). Waiting for Democracy: The Politics of Choice in Natural Resource Decentralisation. Washington, DC: World Resources Institute

Roche, M . Forestgovernanceandsustainabilitypathwaysintheabsenceofa

Rutt, R. L., Myers, R., Ramcilovic-Suominen, S., \& McDermott, C. (2018). FLEGT: Another 'forestry 
fad'?. Environmental Science \& Policy, 89, 266-272.

Sampford, C. (2002). Environmental governance for biodiversity. Environ. Sci. Policy 5(1), 79-90

Sapru, R.K (2010). Public Policy: formulation, implementation \& Evaluation, Sterling, Okhla: New Delhi

Scoones, I. (1998). Sustainable Rural Livelihoods: A Framework for Analysis, IDS Working Paper 72, Brighton: IDS.

Sundström, A. (2016). Understanding illegality and corruption in forest governance. Journal of environmental management, 181, 779-790.

Teketay, D., Lemenih, M., Bekele, T., Yemshaw, Y., Feleke, S., Tadesse, W., ... \& Nigussie, D. (2010). Forest resources and challenges of sustainable forest management and conservation in Ethiopia. Degraded forests in Eastern Africa: management and restoration, 19-63.

Thompson, I., Mackey, B., McNulty, S. \&Mosseler, A. (2009). Forest Resilience, Biodiversity, and Climate Change. A synthesis of the biodiversity/resilience/stability relationship in forest ecosystems. Secretariat of the Convention on Biological Diversity, Montreal. Technical Series no.

Thomson, A.M., Perry, J.L. \& Miller, T.K. (2007).Conceptualizing and Measuring Collaboration. Journal of Public Administration Research and Theory, 19, 23-56.

UNDP (2013). Governance for Sustainable Human Development, New York: UNDP.

Van Gossum, P., Arts, B., Wulf, R., \& de Verheyen, K. (2011). An institutional evaluation of sustainable forest management in Flanders. Land Use Policy, 28, 110-123

Van Tatenhove, J.P.M.; Arts, B.; Leroy, P. Political Modernization and the Environment: The Renewal of Environmental Policy Arrangements; Kluwer Academic Publishers: Dorerecht, The Netherlands, 2000

Vatn, A. (2010). An institutional analysis of payments for environmental services. Ecological economics, 69(6), 1245-1252.

Veenman, S., Liefferink, D., Arts, B. (2009). A short history of Dutch forest policy: The "de institutionalisation" of a policy arrangement. For. Policy Econ., 11, 202-208

Wit, M, Van Dam, J, Cerutti, P. O, Lescuyer, G, Kerret, R \& Parker McKeown, J (2010). Chainsaw milling: supplier to local markets - A synthesis. European Tropical Forest Research Network (ETFRN) News 52: viixxii.

Wodschow, A., Nathan, I., \& Cerutti, P. (2016). Participation, public policy-making, and legitimacy in the EU Voluntary Partnership Agreement process: The Cameroon case. Forest Policy and Economics, 63, 110. 